\title{
Life cycle assessment of pilot-scale wood fibre production using mechanical disc refining at different pressures
}

Skinner, Campbell; Stefanowski, Bronia; Heathcote, Derek; Charlton, Adam; Ormondroyd, Graham

\section{International Wood Products Journal}

DOI:

$10.1080 / 20426445.2016 .1200825$

Published: 01/01/2016

Peer reviewed version

Cyswllt i'r cyhoeddiad / Link to publication

Dyfyniad o'r fersiwn a gyhoeddwyd / Citation for published version (APA):

Skinner, C., Stefanowski, B., Heathcote, D., Charlton, A., \& Ormondroyd, G. (2016). Life cycle assessment of pilot-scale wood fibre production using mechanical disc refining at different pressures. International Wood Products Journal, 7(3), 149-155.

https://doi.org/10.1080/20426445.2016.1200825

\footnotetext{
Hawliau Cyffredinol / General rights

Copyright and moral rights for the publications made accessible in the public portal are retained by the authors and/or other copyright owners and it is a condition of accessing publications that users recognise and abide by the legal requirements associated with these rights.

- Users may download and print one copy of any publication from the public portal for the purpose of private study or research.

- You may not further distribute the material or use it for any profit-making activity or commercial gain

- You may freely distribute the URL identifying the publication in the public portal ?
}

Take down policy

If you believe that this document breaches copyright please contact us providing details, and we will remove access to the work immediately and investigate your claim. 
Life Cycle Assessment of pilot scale wood fibre production using mechanical disc refining at different pressures

\title{
Skinner Campbell ${ }^{1 *}$ Stefanowski Bronia K. ${ }^{1}$ Heathcote Derek $^{1}$ Charlton Adam ${ }^{1}$
} and Ormondroyd Graham A. ${ }^{1,2}$

1 The BioComposites Centre, Bangor University, Bangor, LL57 2UW

${ }^{2}$ Department of Architecture and Civil Engineering, University of Bath, Claverton Down, Bath, BA2 7AY, UK

* Corresponding author c.skinner@bangor.ac.uk, +44 (0) 1248382605

\begin{abstract}
This paper assesses the environmental impact of pilot-scale wood fibre production across a range of refining pressures using energy monitoring at an individual component level. Under optimal refining conditions (8 bar refining pressure; $15 \mu \mathrm{m}$ plate gap width), electricity use accounted for $88 \%$ of GHG emissions associated with the fibre production, and was the dominant input in almost all other impact categories. At an individual component level, the refiner, dryer fan and hot oil burner were the most significant parts of the process (representing 30\%, 20\% and $16 \%$ of cradle-to-gate GHGs respectively), while ancillary processes such as the air compressor (6.9\%) and dust extraction (6.3\%) also made notable contributions. The analysis suggests that energy efficiencies made with these key components may offer the best potential gains in terms of the environmental profile of pressurised refining, as long as these can be achieved without compromising yield or quality of the fibre produced.
\end{abstract}

\section{Key words}

Wood fibre, mechanical disc refining, pressurised refining, MDF, life cycle assessment, LCA, energy use 


\section{Introduction}

\subsection{Pressurised mechanical disc refining}

The mechanical disc refining of wood fibres at different pressures has been the subject of research for many years, but this has primarily focused on the panel products industry and the effect of the refiner pressures on the final board quality (Snell et al., 2001; Krug and Kehr, 2001; Kelley et al., 2005; Xing et al., 2006; Källbom, et al., 2014; Ormondroyd et al., 2016). Krug and Kehr (2001) suggested that increasing the steam pressure results in shorter fibre lengths and lower strength and elastic properties while improving long term swelling properties of the resulting boards. Roffael et al. (2001) found that high pulping temperature results in lower thickness swelling and water absorption with MDF panels. Xing et al. (2006) noted that the refining of juvenile tops of black spruce (Picea mariana) at different pressures had considerable effect on the modulus of elasticity, water absorption, thickness swelling and linear expansion of boards made from this wood. They also found that the interaction between steam pressure and retention time was significant for modulus of rupture. Ormondroyd et al. (2016) assessed the use of changing refiner pressures to tune the surface energy of the refined fibre, which in turn could allow an improvement in the compatibility of the fibre to different resin types.

In addition to the production of wood fibre for MDF manufacture, there is increasing recognition that the technology has other potential applications, for instance in the pretreatment of lignocellulosic biomass for the production of advanced biofuels. A range of biomass pre-treatments have been developed to deconstruct the polymers ( 66 and C5) in lignocellulosic materials, for conversion into fermentable sugars (Kumar et al., 2009). There are limitations to some of these techniques, including the high energy demands required to achieve cell wall disruption and the formation of chemical species that inhibit yeast growth (Jonsson and Martin, 2016), and which can reduce conversion efficiencies of the downstream fermentation process. Optimizing pre-treatment is therefore a key step in the commercial viability of many biotransformation processes and remains a challenge in the production of advanced biofuels. Continuous pressurised refining offers an alternative to more conventional pre-treatment technologies and there are reports of the use of this approach in the pre-treatment of both hard and softwood residues (Koo et al., 2011) and straw (Fang et al., 2011). 
Whilst the primary role of changing the refiner pressure is, in the case of panel production, to give the most appropriate fibre architecture, these changes will have an effect on the energy requirements and will therefore affect both the economic and environmental viability of the whole production process.

\subsection{Life cycle assessment}

Life cycle assessment (LCA) is a method by which the environmental impacts of production can be quantified and evaluated. The approach is defined by the ISO 14040 and 14044 standards (International Organization for Standardization, 2006a; 2006b) which set out a four stage process. By defining a production system (in LCA terminology, a system boundary) and then compiling a comprehensive inventory of the mass and energy balances across this system, environmental impact data can be linked to each of the material and energetic flows. This inventory is then converted into an environmental profile using one of a number of established Impact Assessment methods. The resulting output covers a range of eco-indictors, spanning ecosystem quality (e.g. climate change, eutrophication, acidification), human health factors (e.g. particulate matter, photochemical oxidant formation) and resource depletion (water, fossil fuels and metals). This kind of analysis is increasingly important to producers who see consumers and policy makers drive a shift towards more sustainable production and, in particular, a de-carbonisation of production systems.

In terms of wood panel production, LCA has previously been used in studies of MDF (e.g. Rivela et al., 2007, Werner et al., 2007), oriented strand board (e.g. Kline et al., 2005), particleboard (Rivela et al., 2006) and laminated veneer lumber production (Wilson and Dancer, 2004). Xu et al. (2008) used the approach to assess a composite of wood fibre and polypropylene, demonstrating that the composite performed better than a functionally equivalent product consisting of polypropylene alone. Drawing comparisons of products based on results published across different LCA reports can be challenging though. Studies are typically geographically specific, may use different assessment protocols, and can be based on a variety of sources for secondary data (Hill et al., 2015). Environmental Product Declaration (EPD) schemes go some way to addressing this by defining specific product category rules (PCRs) to unify the criteria against which LCA studies are calculated for a given product sector. Using LCA data drawn from the largest of these schemes, Hill (2015) compared greenhouse gas (GHG) 
emissions and embodied energy associated with a given mass of a range of wood panel products (specifically, fibreboard, particleboard, OSB, Glulam / laminated veneer lumber and solid wood). The analysis showed considerable scatter within the results for each product category but that, overall, fibreboard tended to have the highest results in both impact categories. Further analysis of the impacts associated with fibreboard production is therefore worthwhile.

Considering fibre production specifically, previous LCA research has only been undertaken within a broader analysis of fibre-based panel production, most notably MDF. These studies have shown that wood refining is the most energy intensive step of the process, with fibre production accounting for over half of the total process energy required for board manufacture (Werner et al., 2007). More specifically, Rivela et al. (2007) demonstrated that their 'wood preparation' stage (consisting of all steps associated with wood chip production and delivery, pressurised refining, resination and drying) accounted for $94 \%$ of the fossil fuel requirement and $88 \%$ of GHG emissions associated with industrial-scale MDF production. Another study, based on Canadian MDF production (Athena, 2013) broke this down further. Their analysis found that $49.9 \%$ of cradle-to-gate GHGs (196 kg CO 2 eq. per $\mathrm{m}^{3} \mathrm{MDF}$ ) were associated with on-site wood preparation (i.e. debarking, chipping, refining, resination and blow-line operation only) and $20.1 \%$ (79 kg CO 2 eq. per $\mathrm{m}^{3} \mathrm{MDF}$ ) with drying.

It is therefore clear that fibre production and drying are the most energy and carbon intensive stages of the MDF production process, however little or no published LCA data exists to break this down into the various sub-processes within these two stages. This limits the ability to understand which of these sub-processes are most important in terms of their contribution to the whole, and therefore which represent the environmental hotspots of the fibre production process. Additionally, it hinders accurate modelling of the effects of altering specific refiner parameters (e.g. refiner pressure, plate gap width and configuration, and feed screw settings) using only the existing data.

This study reports data for wood fibre production and the effect that varying the refiner pressure has on the LCA of the overall process. Trials were run at pilot-scale so the results are not directly comparable with those of highly optimised industrial-scale operations, however it remains interesting to understand how specific changes in 
refining conditions may affect the overall environmental performance of this key process in the MDF production pathway.

The functional unit of this study (i.e. the unit against which the results are calculated and reported) was one kilogram of unresinated wood fibres at 9\% moisture content (equivalent to $0.917 \mathrm{~kg}$ oven dry weight). This is a typical moisture content for wood fibre used in commercial MDF production and prior to resination. The system boundary was extended back to the 'cradle' to encompass upstream forestry processes, delivery, and preparation of wood chips, though there is also consideration of the shorter gateto-gate system, in terms of assessing the impacts of energy use when converting chips to dried fibre (figure 1).

\section{Materials and methods}

\subsection{Fibre production}

A commercial mix of spruce, pine and fir chips was received from Kronospan (Chirk, UK). The chips were in a green state with a moisture content of $\sim 120 \%$. The chips were refined at the BioComposites Centre's Bio-Refining Technology Transfer Centre (Mona, Anglesey, UK). The refining was undertaken with an Andritz Sprout-Bauer 12-in pressurised refiner. The refiner was fed from a hopper, through a plug screw feeder or MSD (modular screw device) that moved the chips from the atmospheric to the desired refining pressure. The chips were then fed into a cooker screw and then into a 60 litre digester. The nominal residence time for the material in the cooker screw and in the digester was 60 seconds. After this, the chips were fed through a screw feed into the refining zone, consisting of two, 12 inch diameter refiner plates, with a parallel bar configuration, where the fibre was formed. The refined fibres were then vented through a blow line into the continuous flash dryer. The air velocity in the flash dryer was approximately $51 \mathrm{~m} \mathrm{~s}^{-1}$, and the fibre residence time in the dryer was approximately four seconds, resulting in an end moisture content of $8 \%-10 \%$.

The refiner pressure in the cooker screw and digester were varied between 6, 8 and 10 bar. The refiner run was started at 6 bar and the system stabilised, fibre was produced and stored before the pressure was raised to $8 \mathrm{bar}$, the refiner was then allowed to stabilise and fibre was again produced. This was then repeated for the 10 bar run. In each case, fibre was produced under steady state for 20 minutes at each setting and the 
yield of fibre produced was recorded. All three trials were then repeated under the same conditions using a lower feed screw speed. Finally a 40 minute trial at 8 bar, using a shorter plate gap width $(10 \mu \mathrm{m})$ was performed to give a range of test conditions (table 1).

\subsection{Life cycle assessment}

Throughout the trials, real-time electricity consumption was recorded for each piece of machinery using hardwired OWL +USB energy monitors and associated data logging devices. After the trials, data was downloaded using the proprietary software (OWL Energy Monitoring Systems) and exported into Excel for analysis. The heat requirement, for steam generation and fibre drying, was calculated theoretically owing to an absence of isolated metering at the gas inlet pipes for these two pieces of machinery. This was achieved based on the specific heat capacities of water and air and an assumed boiler efficiency of $85 \%$ (U.S. EPA, 2008). In fact, while the pilot-scale plant used gas for heat generation, industrial-scale panel production typically uses wood fuel (either from waste generated on site or material that is bought in) as the primary fuel for this purpose. Three heat generation scenarios where therefore modelled to reflect a) the actual experimental condition, and b) the conditions more typically employed at an industrial-scale, based on either average or state-of-the-art technology (table 1).

Water was consumed through two processes: as steam for the pressurised cooker function and in a cooling capacity for the refiner plate seals. The quantity required as steam varied with changing refiner pressure, but the seal cooling function used water at a uniform rate, irrespective of refiner conditions or material throughput. The average steam flow rate was therefore recorded directly for each trial to give pressure-specific data for this function. The remaining water (for cooling) was attributed evenly across each trial based on its duration.

Upstream processes were modelled using Ecoinvent v3 LCI data (table 2), accessed via SimaPro v8 software (PRé Consultants B.V., 2014). Data for wood chip production included all upstream forestry operations and was based on softwood forestry with average European production and harvesting techniques. Transportation was modelled to reflect the provenance of the wood used in this trial (in this case, $260 \mathrm{~km}$ by rail from forest to manufacturer) since this was not considered to be untypical of European 
norms. Electricity data was specific to medium voltage UK grid usage.

Material loss during the refining process was assumed to be 1\% (Athena, 2013) and this was assumed to be fed back into energy generation. Air emissions were not directly modelled though a small amount of wood dust is thought to escape to air.

Lifecycle inventory data was then analysed using the ReCiPe v1.11 life cycle impact assessment method (Goedkoop et al., 2008) at midpoint indicator level, using the default hierarchist version. The Cumulative Energy Demand method (Frischknecht et al., 2007) was used to provide additional insight into the non-renewable energy demand of the system.

\section{Results \& discussion}

Table 2 shows the experimental conditions for each trial alongside the recorded average steam flow rate, total electricity consumption, yield, and electricity use as a function of yield. It can be seen that yields varied from $11.9-12.2 \mathrm{~kg}$ per trial at the higher feed screw setting and from $10.0-10.2 \mathrm{~kg}$ per trial at the lower setting. The yield was highest when refining pressure was 8 bar and the plate gap width was $15 \mu \mathrm{m}$, although the differences in yield across the three pressure settings were small. The total electricity demand ranged from 68.6 - $74.5 \mathrm{kWh}$ per hour and was lowest when operating at low feed screw speed and 10 bar of pressure. Given the higher yields recorded at the higher feed screw setting, electricity consumption expressed as a function of output favoured this condition, with both 8 and 10 bar scenarios consuming $2.0 \mathrm{kWh}$ per $\mathrm{kg}$ wood fibre produced (at 6 bar the figure was $2.1 \mathrm{kWh}$ ). This is notably higher than figures reported for commercial-scale operations (Xu et al., 2008 estimated $0.25-0.4 \mathrm{kWh}$ per kg dry fibre, for example) and reflects the pilot-scale nature of the system used here.

The average steam flow rate showed consistency across the 8 bar (173 - $174 \mathrm{~L} \mathrm{~min}^{-1}$ ) and 10 bar (185 - $189 \mathrm{~L} \mathrm{~min}^{-1}$ ) trials, however it varied considerably for the 6 bar trials (87 - $146 \mathrm{~L} \mathrm{~min}^{-1}$ ). This can be explained by the less cohesive nature of the plug that is formed at lower pressures and the irregular flow of the material that ensues. In fact, an earlier trial at 6 bar was abandoned when the lower pressure resulted in a blockage in the blow line. The 6 bar results are therefore included here as a point of comparison. Ormondroyd et al. (2016) showed that the lower the refiner pressure the lower the 
surface energy of the fibres (which in turn affects the gullibility of the fibre) and the higher the equilibrium moisture content of the fibre. They suggested that this was due to varying stages of lignin movement with the differing refiner pressures.

A breakdown of electricity consumption (figure 2) shows that the refiner, dryer fan and hot oil boiler were the most significant consumers of electricity in all trial conditions. In the most efficient scenario (trial 2), the refiner accounted for 34\% of total electricity consumption, the dryer fan $22 \%$ and the hot oil boiler 19\%. The air compressor (which operates the valve for the oil pump), extractor fan and hot oil pump also made notable contributions, representing $8 \%, 7 \%$ and $6 \%$ of total electricity usage respectively. The steam boiler (3\%) and cyclone rotary value (2\%) made up the remaining fraction. When considered on a functional basis, i.e. as either refining or drying operations (figure 1), it can be seen that the refining operation accounts for $36 \%$ of electrical energy consumption and the drying function $64 \%$.

Figure 3 shows the effect of the heat generation scenario on the GHG emissions profile of the overall process energy requirement. It can be seen that GHGs relating to heat generation can vary from $54 \%$ of the total (as in the experimental condition, S1) to as low as 6.3\% in the more industrially-focused biomass based scenarios (S2 and S3). In practice, S1 is only applicable to the pilot-scale processing facilities used here, so these figures reinforce the position that electricity dominates the process energy GHG burden of industrial-scale operation. However, it can also be seen that wherever biomass is used to generate at least $15 \%$ of the heat requirement (as is easily the case in the two industrial scenarios) then electricity usage becomes the most relevant factor in terms of GHG emissions from process energy.

Extending the analysis to include the upstream processes involved in wood chip production (including forestry) and delivery, it can be seen that the electricity demand remains the most significant factor in terms of climate change impact (figure 4). Based on the S3 analysis, electricity makes up $88 \%$ of cradle-to-grave GHG emissions, with heat generation and the remaining inputs representing 5.9\% each. This implies that producers wishing to reduce their carbon footprints may achieve the best returns by focusing in on the electrical hotspots within the production process, as well as on some ancillary components that may not otherwise been seen as priorities in this regard (e.g. dust extraction, air compression). Electricity used by the refiner, for example, 
represents 30\% of cradle-to-gate GHG emissions, followed by the dryer fan (20\%), hot oil burner (16\%), air compressor (7\%) and extractor fan (6\%).

Looking at the full LCA results (table 4) it can be seen that the carbon footprint of the production system varies from 1.5 - $2.9 \mathrm{~kg} \mathrm{CO} 2 \mathrm{e}$ per $\mathrm{kg}$ dried fibre at this scale, depending on the heat generation scenario. As expected, this is higher than figures reported for industrial-scale studies, which report figures of $0.64 \mathrm{~kg} \mathrm{CO} 2 \mathrm{e}$ (Athena, 2013) - $1.2 \mathrm{~kg} \mathrm{CO} 2 \mathrm{e}$ (Werner et al., 2007) per kg finished MDF (assuming a material density of $615 \mathrm{~kg} \mathrm{~m}^{3-1}$ at $8 \%$ water content (Rivela et al., 2007)). This reflects the pilotscale nature of the equipment used here and the optimization that is achievable through scaling up to commercial levels of production. The non-renewable energy consumption varied from $24-36 \mathrm{MJ} \mathrm{kg}^{-1}$ dried fibre, again depending on the heat scenario. When considered in the whole, the environmental profile shows a pattern that largely mirrors that of the grid electricity generation, reflecting the dominance of electricity as an input in the production process. It should be noted that these figures are particular to UK production, given the UK-specific grid electricity LCI data used in this analysis. The carbon-intensity of grid electricity at a national level varies considerably across the EU and beyond it (e.g. see DEFRA, 2015), so studies at other national levels should use data particular to their grid.

\section{Conclusion}

The yields and total energy consumption recorded during this study are not intended to be competitive with those reported for fully-optimised industrial-scale operations. The equipment used here was a small pilot-scale plant used for research and development scale-up work. However, the data presented in this study provides a more detailed insight into the electrical demands during wood refining than is currently available through the existing LCA data, and over a range of refiner pressures.

Key to establishing the role of electricity in the overall environmental profile of fibre production is an understanding of the heat generation scenario employed. While the pilot plant used $100 \%$ gas for this purpose, industrial refiners use either a mix of gas and biomass (typically 38:62) or $100 \%$ biomass (in the most modern operations). By modelling each of these scenarios, the results here have reiterated the dominance of electricity in the environmental profile of industrial-scale fibre production. 
In the $100 \%$ biomass scenario, and at the most efficient operating conditions ( 8 bar refining pressure; $15 \mu \mathrm{m}$ plate gap width), electricity represented $88 \%$ of cradle-to-gate GHGs emissions and was the major contributor to most of the other impact categories (the exceptions being photochemical oxidant formation, agricultural land occupation and water depletion).

At a component level, the analysis has shown that the refiner, dryer fan and hot oil boiler are all key pieces of machinery in terms of electrical energy consumption (representing 74\% of usage collectively) and cradle-to-gate GHG emissions (66\% of the total collectively). Additionally, it has shown that ancillary processes, such as air compression (8\% electricity; 7\% GHGs) and dust extraction (7\% electricity; 6\% GHGs) should not be overlooked.

Variation in refining pressure resulted in small differences in overall energy consumption at each setting, with 8 and 10 bar refining using a total of $2.0 \mathrm{kWh}$ per $\mathrm{kg}$ dried fibre and 6 bar refining using $2.1 \mathrm{kWh}$. Additional trials may now be beneficial to establish whether this difference is significant or not. At a functional level, the usage broke down as 36\% from components involved in the refining process itself and $64 \%$ from those involved in drying.

The analysis suggests the manufacturers wishing to improve the environmental performance of their wood fibre production facilities should focus on key electricity consuming components such as the refiner, dryer fan and hot oil boiler, and on other significant ancillary processes such as dust extraction and air compression. These are the components where percentage improvements in energetic performance offer the greatest potential for environmental gain.

\section{Acknowledgements}

The research leading to these results has received funding from BEACON (funded by the European Regional Development Fund and Welsh Government) and the European Union's Seventh Framework Programme (FP7/2007-2013) for research, technological development and demonstration under grant agreement no 609234.

\section{References}


Athena, 2013. A cradle-to-gate life cycle assessment of Canadian medium density fibreboard (MDF), 2013 update, Athena Sustainable Materials Institute, Ottawa, Canada.

CEN, 2012. Sustainability of construction works. Environmental product declarations. Core rules for the product category of construction products, Brussels, European Committee for Standardisation.

DEFRA, 2015. Greenhouse gas conversion factor repository. [online] Available at: http://www.ukconversionfactorscarbonsmart.co.uk [Accessed 25 November 2015].

Fang, H., Deng, J., Zhang, X. 2011. Continuous steam explosion of wheat straw by high pressure mechanical refining system to produce sugars for bioconversion, BioResources, 6, (4), 4468-4480.

Frischknecht, R., Jungbluth, N., Althaus, H. J., Doka, G., Dones, R., Hischier, R., Hellweg, S., Humbert, S., Margni, M., Nemecek, T., Spielmann, M. 2007. Implementation of Life Cycle Impact Assessment Methods: Data v2.0. ecoinvent report No. 3, Swiss Centre for Life Cycle Inventories, Dübendorf, Switzerland.

Goedkoop, M. J., Heijungs, R., Huijbregts, M., De Schryver, A., Struijs, J., Van Zelm, R. 2008). ReCiPe 2008, A life cycle impact assessment method which comprises harmonised category indicators at the midpoint and the endpoint level; First edition Report I: Characterisation. [online] Available at: http://www.lcia-recipe.net [Accessed 25 November 2015].

Hill, C. 2015. The environmental impact of wood compared to other building materials the impact of European standard EN15804, in Proceedings of the International Panel Products Symposium, 7-8th October 2015, Llandudno, UK.

Hill, C., Norton, A., Kutnar, A. 2015. Environmental impacts of wood composites and legislative obligations, in Wood composites, (ed. M. Ansell), 311-333, Cambridge, Woodhead Publishing.

International Organization for Standardization, 2006a. ISO 14040 Environmental management - life cycle assessment - principles and framework, International Organization for Standardization, Geneva, Switzerland.

International Organization for Standardization, 2006b. ISO 14044 Environmental management - life cycle assessment - requirements and guidelines, International Organization for Standardization, Geneva, Switzerland.

Jonsson, L. J. and Martin, C. 2016. Pretreatment of lignocellulose: formation of inhibitory by-products and strategies for minimizing their effects, Bioresource Technol., 199, 103-112. 
Källbom, S., Ormondroyd, G. A., Segerholm, B. K., Jones, D., Wålinder, M. E. P. 2014. Surface energy characteristics of fibres refined at different pressures, Northern European Wood Science and Technology Conference 2014, Edinburgh, UK.

Kelley, S. S., Elder, T., Groom, L. H. 2005. Changes in the chemical composition and spectroscopy of loblolly pine medium density fiberboard furnish as a function of age and refining pressure, Wood and Fiber Sci., 37, (1), 14-22.

Kline, E. D. 2004. Southeastern oriented strandboard production, CORRIM Phase I Final Report Module E. Life cycle environmental performance of renewable building materials in the context of residential construction, Seattle, University of Washington,

Koo, B. W., Treasure, T.H., Jameel, H., Phillips, R. B., Chang, H. M., Park, S. 2011. Reduction of enzyme dosage by oxygen delignification and mechanical refining for enzymatic hydrolysis of green liquor-pretreated hardwood, Appl. Biochem. Biotech., 165, (3-4), 832-844.

Krug, D., Kehr, E. 2001. Influence of high pulping pressures on permanent swellingtempered medium density fibreboards, Holz als Roh- und Werkstoff, 59, (5), 342-343.

Kumar, P., Barrett, D. M., Delwiche, M.J., Stroeve, P. 2009. Methods for pretreatment of lignocellulosic biomass for efficient hydrolysis and biofuel production, Ind. Eng. Chem. Res. , 48, 3713-3729.

Ormondroyd, G. A., Kallbom, S. K., Curling, S. F., Stefanowski, B. K., Segerholm, B. K., Walinder, M. E. P., Jones, D. 2016. Water sorption, surface structure and surface energy characteristics of wood composite fibres refined at different pressures, Wood Mater. Sci. Eng. In Press.

PRé Consultants B.V. 2014. SimaPro LCA software version 8. Amersfoort, Netherlands. [online] Available at: http://www.simapro.co.uk/ [Accessed 26 November 2015].

Rivela, B., Hospido, A., Moreira, M.T., Feijoo, G. 2006. Life cycle inventory of particleboard: a case study in the wood sector. Int. J. Life Cycle Assess., 11, 106-113.

Rivela, B., Moreira, M. T., Feijoo, G. 2007. Life Cycle Inventory of Medium Density Fibreboard, Int. J. Life Cycle Assess., 12, (3), 143-150.

Roffael, E., Dix, B., Schneider, T. 2001. Thermomechanical (TMP) and ChemoThermomechanical Pulps (CTMP) for Medium Density Fibreboard (MDF), Holzforschung, 55, (2), 214-218.

Snell, R., Groom, L. H., Rials, T. G. 2001. Characterizing the Surface Roughness of Thermomechanical Pulp Fibers with Atomic Force Microscopy, Holzforschung, 55, (5), 511-520. 
U.S. EPA, 2008. Climate Leaders Greenhouse Gas Inventory Protocol Offset Project Methodology for Industrial Boiler Efficiency, United States Environment Protection Agency, EPA400-S-08-001.

Weidema, B. P., Bauer, Ch., Hischier, R., Mutel, Ch., Nemecek, T., Reinhard, J., Vadenbo, C. O., Wernet, G. 2013. The ecoinvent database: overview and methodology, data quality guideline for the ecoinvent database version 3. [online] Available at: www.ecoinvent.org [Accessed 26 November 2015].

Werner, F., Althaus, H-J., Künniger, T., Richter, K. 2007. Life cycle inventories of wood as fuel and construction material. Ecoinvent report no. 9, Swiss Centre for Life Cycle Inventories, Dübendorf, Switzerland.

Wilson, J.B. and Dancer, E.R. 2004. Laminated veneer lumber - Pacific Northwest and Southeast, CORRIM Phase I Final Report Module H:

http://www.corrim.org/pubs/reports/2005/Phase1/Module H Final.pdf [Accessed 25 January 2016].

Xing, C., Deng, J., Zhang, S. Y., Riedl, B., Cloutier, A. 2006. Properties of MDF from black spruce tops as affected by thermomechanical refining conditions, Holz als Roh- und Werkstoff, 64, (6), 507-512.

Xu, X., Jayaraman, K., Morin, C., Pecqueux, N. 2008. Life cycle assessment of woodfibre-reinforced polypropylene composites, J. Mater. Process. Tech., 198, 168-177.

\section{Figure and table captions}

Figure 1. System boundary of the modelled wood fibre production process. Dotted line shows the shorter gate-to-gate processes of refining wood chips in to dried fibre. MSD = modular screw device.

Table 1: Modelled heat generation scenarios

Table 2: Life cycle inventory data sources

Table 3: Experimental conditions with average steam flow rate, yield and electrical energy consumption

Figure 2: Comparison and breakdown of electricity usage across the different refiner trials

Figure 3: GHG emissions associated with heat generation, relative to electrical energy consumption, based on three heat generation scenarios ( $\mathrm{S} 1=100 \%$ nat. gas; $\mathrm{S} 2=38 \%$ 
nat. gas, $62 \%$ biomass; S3 = 100\% biomass)

Figure 4: Breakdown of GHG emissions associated with pilot-scale production of $1 \mathrm{~kg}$ wood fibre at 8 bar (trial 2 conditions) using heat scenario 3 (100\% biomass). (Data for wood chips includes all upstream forestry operations)

Table 4: Cradle-to-gate LCA results for pilot-scale production of $1 \mathrm{~kg}$ wood fibre at $8 \mathrm{bar}$ (trial 2 conditions) using ReCiPe and Cumulative Energy Demand mid-point categories and three heat generation scenarios (S1: 100\% nat. gas; S2: 38\% nat. gas, $62 \%$ biomass; S3: $100 \%$ biomass)

Figures

[See as separate files]

Tables

Table 1: Modelled heat generation scenarios

\begin{tabular}{|l|l|l|l|l|}
\hline Scenario & Description & Fuel mix & Detail & Reference \\
\hline 1 & $\begin{array}{l}\text { Pilot-scale } \\
\text { production }\end{array}$ & $100 \%$ nat. gas & Primary data collection & $\ldots$ \\
\hline 2 & Industrial mix 1 & $\begin{array}{l}38 \% \text { nat. gas, } \\
62 \% \text { biomass }\end{array}$ & $\begin{array}{l}\text { Weighted average production of European } \\
\text { Panel Federation members }\end{array}$ & $\begin{array}{l}\text { Werner } \text { et } \\
\text { al., } 2007\end{array}$ \\
\hline 3 & Industrial mix 2 & $100 \%$ biomass & $\begin{array}{l}\text { State-of-the-art facilities in Spain (2) and } \\
\text { Chile (1), production capacity 150,000m }{ }^{3} \text { pa }\end{array}$ & $\begin{array}{l}\text { Rivela } \text { et } \\
\text { al., 2007 }\end{array}$ \\
\hline
\end{tabular}

Table 2: Life cycle inventory data sources

\begin{tabular}{|l|l|l|}
\hline Input & Unit & ecoinvent dataset \\
\hline Wood chips* & kg & Wood chips, wet, measured as dry mass, RER \\
\hline Electricity & kWh & Electricity, medium voltage, GB \\
\hline Heat, natural gas & MJ & Heat, central or small-scale, natrual gas, Europe excl. CH, \\
\hline Heat, biomass & MJ & $\begin{array}{l}\text { Wood chips, from industry, softwood, burned in furnace } \\
50 \mathrm{~kW}, \mathrm{CH}\end{array}$ \\
\hline Transport & tkm & Freight train, Europe excl. $\mathrm{CH}$ \\
\hline Water & $\mathrm{kg}$ & Tap water, Europe excl. $\mathrm{CH}$ \\
\hline
\end{tabular}

* Data for wood chips includes upstream forestry operations

Table 3: Experimental conditions with average steam flow rate, yield and electrical energy 
consumption

\begin{tabular}{|c|c|c|c|c|c|c|c|c|}
\hline Trial & $\begin{array}{c}P \\
\text { (ba } \\
\text { r) }\end{array}$ & $\begin{array}{l}\text { Time } \\
(\min \\
\mathrm{s})\end{array}$ & $\begin{array}{c}\text { Feed } \\
\text { screw } \\
\text { speed } \\
\text { (low/high } \\
\text { ) }\end{array}$ & $\begin{array}{l}\text { Plate } \\
\text { gap } \\
\text { width } \\
(\mu \mathrm{m})\end{array}$ & $\begin{array}{c}\text { Ave } \\
\text { steam } \\
\text { flow rate } \\
\left(\mathrm{L} \mathrm{min}^{-1}\right)\end{array}$ & $\begin{array}{c}\text { Total } \\
\text { electricity } \\
\text { use (kWh) }\end{array}$ & $\begin{array}{r}\text { Yield } \\
(\mathrm{kg})\end{array}$ & $\begin{array}{c}\text { Electricity use } \\
\text { by yield (kWh } \\
\mathrm{kg}^{-1} \text { fibre) }\end{array}$ \\
\hline 1 & 6 & 20 & $\mathrm{H}$ & 15 & 145.8 & 24.8 & 11.9 & 2.1 \\
\hline 2 & 8 & 20 & $\mathrm{H}$ & 15 & 173.8 & 24.0 & 12.2 & 2.0 \\
\hline 3 & 10 & 20 & $\mathrm{H}$ & 15 & 189.1 & 24.0 & 11.9 & 2.0 \\
\hline 4 & 6 & 20 & $\mathrm{~L}$ & 15 & 87.4 & 24.2 & 10.0 & 2.4 \\
\hline 5 & 8 & 20 & $\mathrm{~L}$ & 15 & 172.9 & 24.4 & 10.1 & 2.4 \\
\hline 6 & 10 & 20 & $\mathrm{~L}$ & 15 & 185.2 & 22.9 & 10.2 & 2.2 \\
\hline 7 & 8 & 40 & $\mathrm{~L}$ & 10 & 159.0 & 46.2 & 21.0 & 2.2 \\
\hline
\end{tabular}

Table 4: Cradle-to-gate LCA results for pilot-scale production of $1 \mathrm{~kg}$ wood fibre at 8 bar (trial 2 conditions) using ReCiPe and Cumulative Energy Demand mid-point categories and three heat generation scenarios (S1: 100\% nat. gas; S2: 38\% nat. gas, 62\% biomass; S3: 100\% biomass)

\begin{tabular}{|l|l|l|l|l|}
\hline Impact category & Unit & S1 & S2 & S3 \\
\hline Climate change & kg CO2 eq & $2.9 \mathrm{E}+00$ & $2.0 \mathrm{E}+00$ & $1.5 \mathrm{E}+00$ \\
\hline Ozone depletion & kg CFC-11 eq & $1.8 \mathrm{E}-07$ & $1.2 \mathrm{E}-07$ & $9.3 \mathrm{E}-08$ \\
\hline Terrestrial acidification & kg SO2 eq & $1.0 \mathrm{E}-02$ & $8.5 \mathrm{E}-03$ & $7.3 \mathrm{E}-03$ \\
\hline Freshwater eutrophication & kg P eq & $4.3 \mathrm{E}-04$ & $4.4 \mathrm{E}-04$ & $4.5 \mathrm{E}-04$ \\
\hline Marine eutrophication & kg N eq & $2.2 \mathrm{E}-02$ & $2.2 \mathrm{E}-02$ & $2.1 \mathrm{E}-02$ \\
\hline Human toxicity & kg 1,4-DB eq & $4.2 \mathrm{E}-01$ & $4.3 \mathrm{E}-01$ & $4.3 \mathrm{E}-01$ \\
\hline Photochemical oxidant formation & kg NMVOC & $5.2 \mathrm{E}-03$ & $5.6 \mathrm{E}-03$ & $5.9 \mathrm{E}-03$ \\
\hline Particulate matter formation & $\mathrm{kg} \mathrm{PM10} \mathrm{eq}$ & $2.8 \mathrm{E}-03$ & $3.0 \mathrm{E}-03$ & $3.1 \mathrm{E}-03$ \\
\hline Terrestrial ecotoxicity & $\mathrm{kg} \mathrm{1,4-DB} \mathrm{eq}$ & $2.2 \mathrm{E}-04$ & $2.1 \mathrm{E}-04$ & $2.0 \mathrm{E}-04$ \\
\hline Freshwater ecotoxicity & $\mathrm{kg} \mathrm{1,4-DB} \mathrm{eq}$ & $2.3 \mathrm{E}-02$ & $1.9 \mathrm{E}-02$ & $1.6 \mathrm{E}-02$ \\
\hline Marine ecotoxicity & $\mathrm{kg} 1,4-\mathrm{DB}$ eq & $1.8 \mathrm{E}-02$ & $1.7 \mathrm{E}-02$ & $1.6 \mathrm{E}-02$ \\
\hline lonising radiation & $\mathrm{kBq} \mathrm{U} 235$ eq & $4.4 \mathrm{E}-01$ & $4.7 \mathrm{E}-01$ & $4.8 \mathrm{E}-01$ \\
\hline Agricultural land occupation & $\mathrm{m} 2 \mathrm{a}$ & $2.5 \mathrm{E}+00$ & $2.7 \mathrm{E}+00$ & $2.8 \mathrm{E}+00$ \\
\hline Urban land occupation & $\mathrm{m} 2 \mathrm{a}$ & $3.4 \mathrm{E}-02$ & $3.8 \mathrm{E}-02$ & $4.0 \mathrm{E}-02$ \\
\hline Natural land transformation & $\mathrm{m} 2$ & $5.1 \mathrm{E}-04$ & $4.5 \mathrm{E}-04$ & $4.1 \mathrm{E}-04$ \\
\hline Water depletion & $\mathrm{m} 3$ & $3.5 \mathrm{E}-02$ & $4.1 \mathrm{E}-02$ & $4.5 \mathrm{E}-02$ \\
\hline Metal depletion & $\mathrm{kg} \mathrm{Fe} \mathrm{eq}$ & $4.6 \mathrm{E}-02$ & $4.0 \mathrm{E}-02$ & $3.6 \mathrm{E}-02$ \\
\hline Non-renewable energy* & $\mathrm{MJ}$ & $3.6 \mathrm{E}+01$ & $2.9 \mathrm{E}+01$ & $2.4 \mathrm{E}+01$ \\
\hline
\end{tabular}




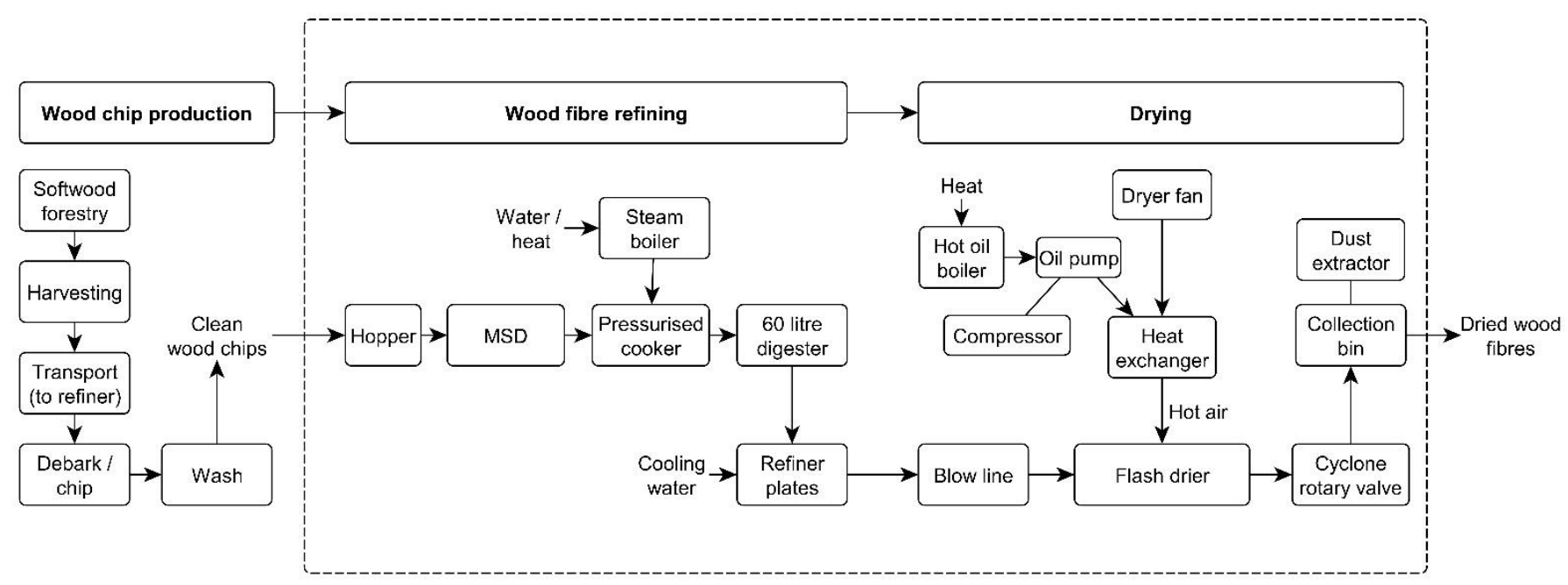

Figure 1. System boundary of the modelled wood fibre production process. Dotted line shows the shorter gate-to-gate processes of refining wood chips in to dried fibre.

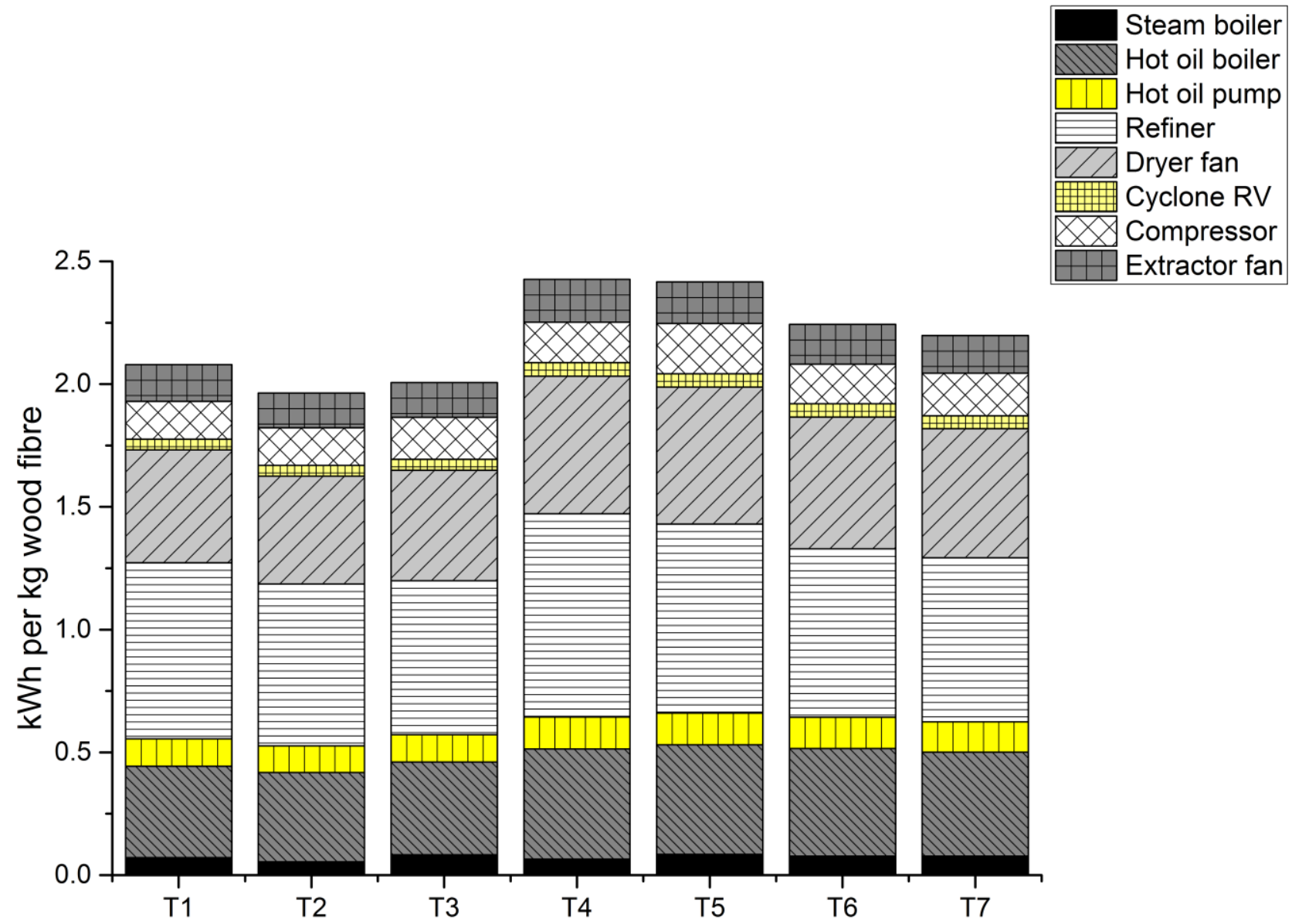

Figure 2: Comparison and breakdown of electricity usage across the different refiner trials. 


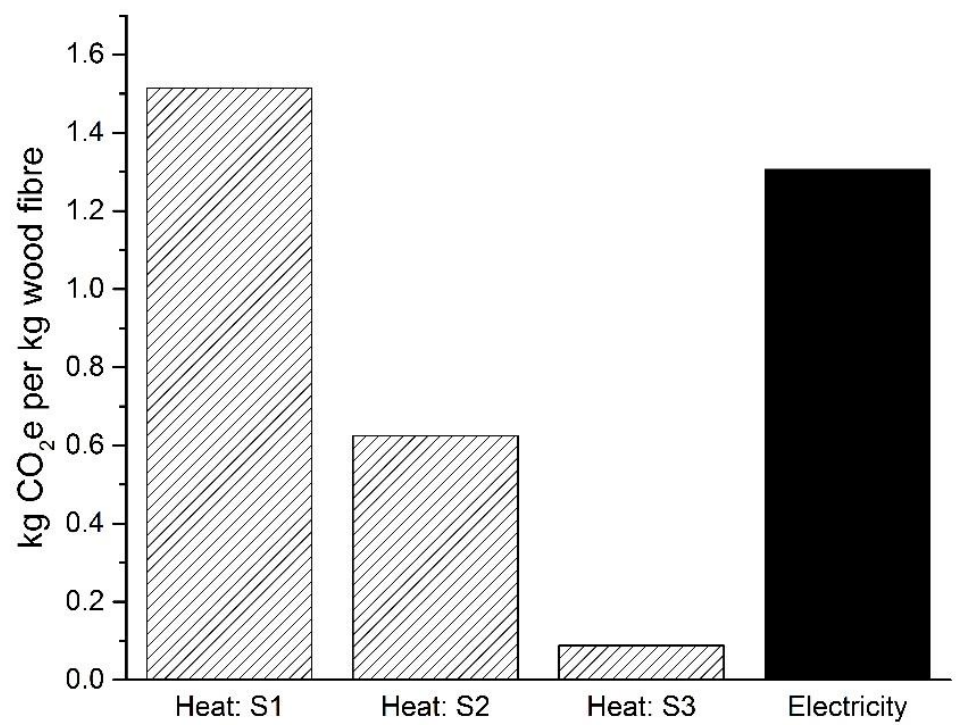

Figure 3: GHG emissions associated with heat generation, relative to electrical energy consumption, based on three heat generation scenarios ( $\mathrm{S} 1=100 \%$ nat. gas; $\mathrm{S2}=38 \%$ nat. gas, $62 \%$ biomass; $\mathrm{S} 3=$ 100\% biomass) 


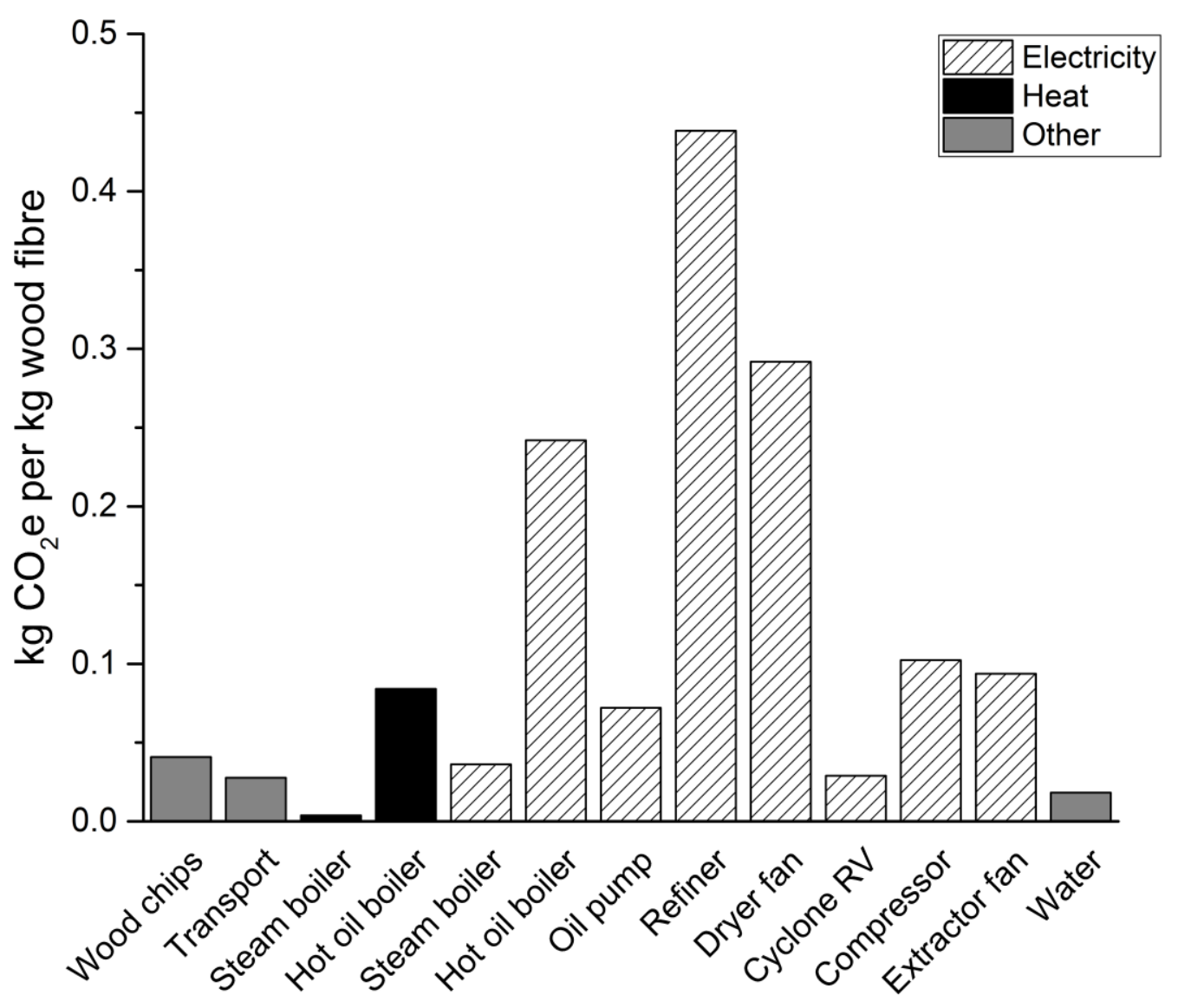

Figure 4: Breakdown of GHG emissions associated with pilot-scale production of $1 \mathrm{~kg}$ wood fibre at 8 bar (trial 2 conditions) using heat scenario 3 (100\% biomass). (Data for wood chips includes all upstream forestry operations). 